\title{
Empirical Study on Water Ecological Compensation Mechanism Across Provinces-Taking the Key Trans Provincial Section of Longnan as an Example
}

\author{
$\mathrm{Li} \mathrm{Jie}^{1}$, Song Xiaoyu ${ }^{2, *}$ \\ ${ }^{1}$ College of Geography and Environment Science, Northwest Normal University, Lanzhou, China \\ ${ }^{2}$ Cold and Arid Regins Environmental and Engineering Research Institute, Chinese Academy of Science, Lanzhou, China
}

\section{Email address:}

ljxbsd@139.com (Li Jie),song9901@163.com (Song Xiaoyu)

*Corresponding author

\section{To cite this article:}

Li Jie, Song Xiaoyu. Empirical Study on Water Ecological Compensation Mechanism Across Provinces-Taking the Key Trans Provincial Section of Longnan as an Example. Science Discovery. Vol. 6, No. 5, 2018, pp. 358-366. doi: 10.11648/j.sd.20180605.18

Received: August 11, 2018; Accepted: October 8, 2018; Published: October 18, 2018

\begin{abstract}
The practice of inter provincial basin of water ecological compensation is less in China, the main difficulties are the imperfection of the current government system and the unclear negotiation process between upstream and downstream. Longnan is located in the upper reaches of the three provinces. Promoting the work of inter provincial basin of water ecological compensation between Longnan and downstream provinces actively is meaningful for promoting the sustainable development of water ecology in river basins. According to the investigation on the spot, the cost of sewage disposal in different water quality of different inter provincial basin in Longnan is calculated, and the relevant compensation agreements are made. When the water quality of the cross-section is better or worse than the target water quality, Longnan should receive the compensation or pay the money, and the short-term, medium-term and long-term compensation plans are put forward, which provide useful ideas and specific reference schemes for relevant regions to carry out inter-provincial basin water ecological compensation.
\end{abstract}

Keywords: Cross Provincial Section, Ecological Compensation, Empirical Research

\section{跨省断面水生态补偿机制实证研究一以陇南市关键跨省断面为例}

\author{
李洁1, 宋晓谕 ${ }^{*}$ \\ ${ }^{1}$ 地理与环境学院, 西北师范大学, 兰州, 中国 \\ 2寒区旱区环境与工程研究所寒旱区流域水文及应用生态实验室,中国科学院, 兰州, 中国
}

\section{邮箱}

ljxbsd@139.com（李洁）, song9901@163.com（宋晓谕）

\begin{abstract}
摘要: 中国开展跨省流域水生态补偿的实践工作较少，其面临的困境主要是政府现行体制不完善及上下游之间协商流 程不明确等问题。陇南市位于三省交界的上游地区, 积极推进陇南市与下游省份开展跨省流域水生态补偿的实证工作， 对于促进流域水生态可持续发展有至关意义。根据实地走访调查，核算出陇南市各跨省断面不同水质污水处理成本， 制定相关补偿协议，明确断面水质优于或劣于目标水质时，陇南市应得到或支付的赔偿资金及赔付资金，并提出了近 期、中期及远期补偿规划，对相关地区开展跨省流域水生态补偿工作提供了有益思路和具体借鉴方案。
\end{abstract}


关键词: 跨省断面, 生态补偿, 实证研究

\section{1. 引言}

水资源危机是人类进入 21 世纪以来所面临的最严峻 的挑战之一 $[1]$, 生态补偿作为一种最有效的水环境治理手 段,已得到了各国政府、学者的广泛关注及普遍认可[2-5]。 国外比中国更早经历了水污染治理的历史，不同区域之间 制定生态补偿协议对发挥环境正外部性起到了良好的促 进作用。随着中国工业化、城市进程的不断加快，利用生 态补偿模式开展水环境治理工作已成为中国政府治理大 江、大河污染问题的重要手段之一[6-8]。但是，中国幅员 辽阔, 水系发达, 上下游尤其是各省之间为寻求自身发展 矛盾突出, 利益关联复杂。长期以来政府一直以行政区域 为单元, 利用立法的形式强制要求上游地区进行环境保护, 放弃发展权益, 流域生态补偿主体的角色也往往由政府承 担，这种方式并没有真正促进和激励上下游之间特别是不 同行政单元之间自发地承担起相应的治理义务, 形成可持 续发展的共赢局面, 反而模糊了生态补偿作为市场调节工 具的本质。中国学者对跨省流域水环境治理的研究日趋增 多, 但因学科背景和研究侧重点有差异, 对其具体涵义的 理解也各有不同[9-10]。中国跨省流域生态补偿大部分工
作仍停留在研究阶段, 政府内动力不足、外部保障欠缺等 原因使得开展实践工作较少, 但是, 江苏、河南、辽宁、 福建、河北、湖南、浙江、江西、山东、山西、广东、海 南等省已相继出台了有关流域生态补偿的相关政策、法规, 部分地区更是开展了跨省流域生态补偿的具体试点工作, 为弥补中国相关领域的空白做出了有益尝试[11], 例如发 源于安徽省黄山市的新安江是千岛湖优质水源的重要保 证, 2011年, 党和国家领导人先后做出重要批示, 要求皖 浙两省要通力协作, 保证千岛湖的水环境安全[12]。

跨省流域生态补偿的研究大多停留在理论阶段, 内容 集中在水生态补偿的原理、方法及制度的讨论上, 实践工 作有限, 亟待补充具体的实证研究[13-15]。陇南境内有嘉 陵江、白龙江、白水江、西汉水四大水系，大小河流 3760 条, 年径流量 279 亿立方米。其中多条河流最终汇入下游 省份, 对跨省流域的水生态安全及利益产生了至关重要的 影响。因此, 积极推进甘肃省与流域下游省份开展水环境 补偿工作, 使流域上下游省份以协议方式明确各自的职责 和义务, 制定陇南市跨省流域水环境补偿方案, 对促进流 域水资源的可持续利用有重要意义。

\section{2. 研究区概况}

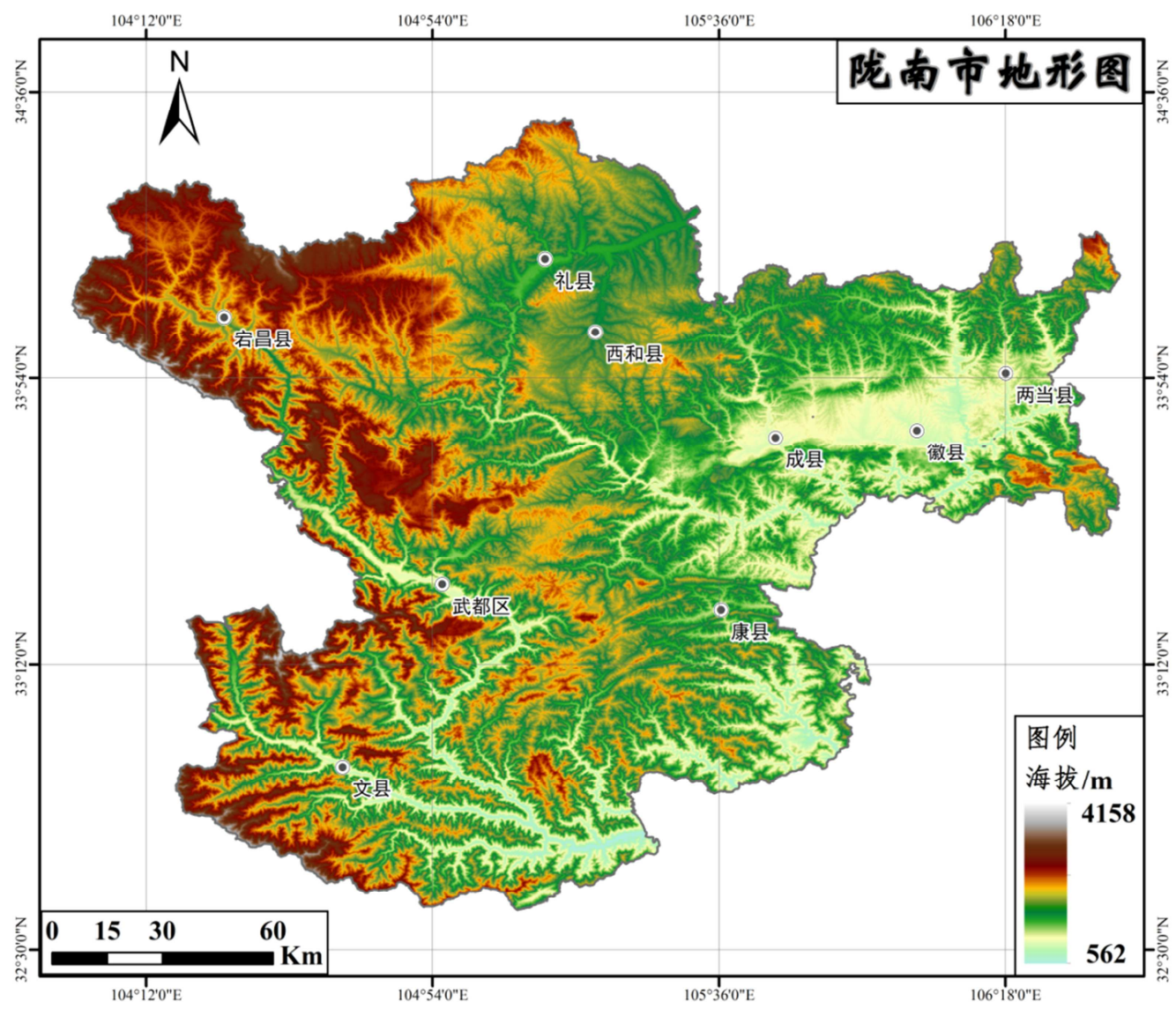

图1 研究区概况。 
陇南市于甘肃省东南部, 地处中国大陆二级阶梯向三 级阶梯过渡地带, 位于秦巴山区、青藏高原、黄土高原三 大地形交汇区域, 东接陕西, 南通四川, 扼陕甘川三省要 冲, 素称 “秦陇锁钥, 巴蜀咽喉”。其地理位置介于东经 $104^{\circ} 01^{\prime} 19^{\prime \prime}$ 至 $106^{\circ} 35^{\prime} 20^{\prime \prime}$, 北纬32 $35^{\prime} 45^{\prime \prime}$ 至 $34^{\circ} 32^{\prime} 00^{\prime \prime}$ 。北与 天水市秦州区、麦积区、武山县、甘谷县接壤; 南抵四川 盆地, 与广元市、青川县、绵阳市平武县和阿坝州九寨沟 县毗连; 西依甘南高原与迭部县、舟曲县和定西市的怅县; 东接秦巴山地, 与陕西省汉中市宁强县、略阳县、勉县和 宝鸡市凤县为邻。陇南是甘肃省唯一属于长江水系并拥有 亚热带气候的地区, 是长江上游重要的水源涵养区和水土 保持区, 也是青藏高原东部边缘重要生态屏障和是中国生 物多样性保护的重点区域, 具有十分重要的生态地位。

\section{3. 数据来源与研究方法}

\section{1. 数据来源}

研究所需的河流径流量数据来源于 《2015年陇南市水 资源公报》，污水处理成本数据来源于陇南市污水处理厂 实地走访调查。

\section{2. 研究方法}

\subsection{1. 水环境污染物排放估算}

$$
\mathrm{D}=\mathrm{R} \times \mathrm{A}
$$

其中, $\mathrm{D}$ 为污染物排放总量, $\mathrm{R}$ 为河流径流量, $\mathrm{A}$ 为水 污染物排系数。

\subsection{2. 污水处理成本估算}

治理污水、核算成本，首先要确定适合区域的污水处 理技术，根据中华人民共和国住房和城市建设部《西北地 区农村生活污水处理技术指南(试行)》[16], 西北大部分 区域干旱缺水, 日照时间长, 生活污水处理应尽量与资源 化利用结合。根据实地走访调查, 陇南地区适合使用 $\mathrm{A} / \mathrm{O}$ 技术进行污水回收处理, 该技术属于生化处理技术, 综合 厌氧、好氧等工艺的特点, 适合具有一定人口规模的村镇 统一回收, 集中处理。 $\mathrm{A} / \mathrm{O}$ 技术采用“初沉调节+厌氧水解 +微动力好氧” 的组合方式(见图2所示), 不仅工艺成熟实用, 操作运行方便, 而且日常费用低廉, 出水稳定。

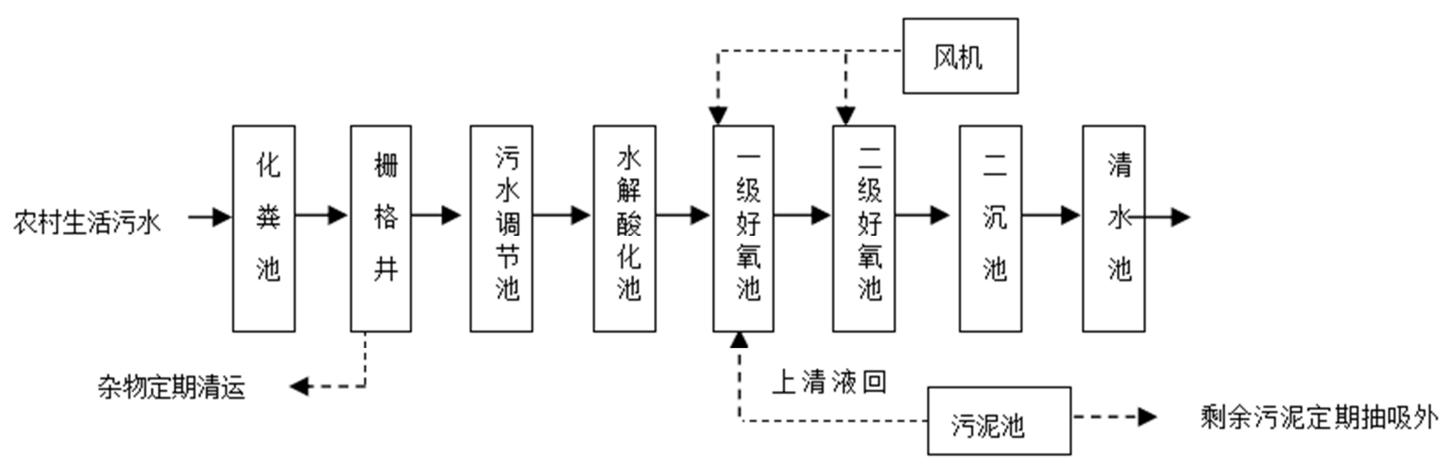

图2 A/O工艺技术示意图。

污水生态补偿治理成本是指为了实现区域内农村居 民生活污水的全面处理所需要投入的设备、设施的购置、 建设费用以及为了维持设备、设施正常运转所需投入的人 力成本、维修维护成本、管理成本等。结合相关研究成果, 可将上述成本费用划分为管道铺设成本(管道购买费用、 安装费用)、设备建设成本(设备购买费用、安装费用)、后 期运营成本(人员工资费用、日常运营检修费用)三类。综 合上述成本费用分类，总治理成本核算方法为:

$$
\begin{gathered}
C_{T}=C_{L}+C_{E}+C_{P} \\
C_{L}=C_{t}+C_{a_{1}}
\end{gathered}
$$

$$
\begin{gathered}
C_{E}=C_{j}+C_{a_{2}} \\
C_{P}=C_{w}+C_{c}
\end{gathered}
$$

式中: $\mathrm{C}_{\mathrm{T}}$ 一总成本, 单位元; $\mathrm{C}_{\mathrm{L}}$ 一排污管道铺设成本, 单位元; $C_{E}$ 一污水设备建设成本, 单位元; $C_{P}$ 一后期运营 成本, 单位元; $\mathrm{C}_{\mathrm{t}}$ 一管道购买费用, 单位元; $\mathrm{C}_{\mathrm{a} 1}$ 一管道安 装费用, 单位元; $C_{j}$ 一污水设备购买费用, 单位元; $C_{a 2}-$ 污水设备安装费用, 单位元; $\mathrm{C}_{\mathrm{w}}$ 一人员工资, 单位元;

\begin{tabular}{|c|c|c|}
\hline 成本种类 & 具体分类 & 核算过程 \\
\hline 排污管道铺设成本 & $\begin{array}{l}\text { 管道购买费用 } \\
\text { 安装费用 }\end{array}$ & $\begin{array}{l}\text { 采用西北地区相关研究的成本核算案例, 计算出西北地区人均管道铺设成本, 根据陇南流域试点村庄 } \\
\text { 人口, 对铺设污水管道的总成本进行大体估算。其中人均管道铺设成本为 } 6.63 \text { 元/人。 }\end{array}$ \\
\hline \multirow[b]{2}{*}{ 污水设备建设成本 } & 设备购买费用 & 本研究前期开展了充分的调研活动, 包括与污水处理设备厂商进行了详细的沟通与了解, 并根据试点 \\
\hline & 安装费用 & $\begin{array}{l}\text { 村庄的人口总数及排污规模, 最终确定了设备的日处理规格为 } 180 \mathrm{~m}^{3} / \text { 天左右, 建设成本总计为 } 7.8 \text { 万元 } \\
\text { 左右。 }\end{array}$ \\
\hline
\end{tabular}
$\mathrm{C}_{\mathrm{c}}$ 一设备修理费用, 单位元。

参考国内相关区域研究成果, 并通过对设备生产、销 售企业咨询，具体核算过程见表 1 。

表1 陇南地区污水处理成本。 


\begin{tabular}{lll}
\hline 成本种类 & 具体分类 & 核算过程 \\
\hline & & 陇南地区农村污水处理试点的人均工资根据区域的经济发展情况略有差异, 平均水平为 1000 元/人/月, \\
& 参考相关科研文献, 日常检修维护费用平均按固定资产的 $4 \%$ 计取, 但由于不同村落人口规模、发展水 \\
后期运营成本 & 人员工资 & 平、集聚程度都有差异, 因此, 仍然按照西北地区相关案例的人均运营成本, 根据研究区人口总数, \\
& & 推算出渭河流域不同试点的总运营成本。其中人均运营成本为 4.08 元/人。 \\
\hline
\end{tabular}

\subsection{3. 单位污水处理成本}

根据实地走访调研, 污水处理设备的日处理能力大约 为 30 万吨/天，根据《西北地区农村生活污水处理技术指 南(试行)》中公布的水质参考标准, 按照处理后的污水排 放基本达到国家要求的一级 $\mathrm{B}$ 的水平, 陇南地区污水处理

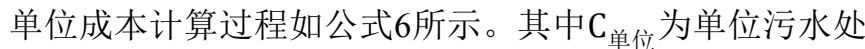
理成本, $\mathrm{C}_{\text {总 }}$ 为污水处理总成本, $\mathrm{P}$ 为污水进水量, $\mathrm{A}_{\text {进为 }}$

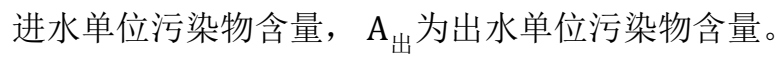

$$
\mathrm{C}_{\text {单位 }}=\mathrm{C}_{\text {总 }} /\left(\mathrm{P} \times \mathrm{A}_{\text {进 }}+\mathrm{P} \times \mathrm{A}_{\text {出 }}\right)
$$

\section{4. 结果与分析}

\section{1. 陇南市跨区域流域断面}

\subsection{1. 陇南市跨省断面}

表2 陇南市跨省断面。

\begin{tabular}{|c|c|c|c|c|c|c|}
\hline 断面名称 & 所在县区 & 所属流域 & 所属水系 & 所属河流 & 流域面积 $\left(\mathrm{km}^{2}\right)$ & 途径省份 \\
\hline 大河店 & 徽县 & 长江流域 & 嘉陵江水系 & 洛河 & 1039 & 甘肃、陕西 \\
\hline 虞关 & 徽县 & 长江流域 & 嘉陵江水系 & 长丰河 & 1841 & 甘肃、陕西 \\
\hline 托河 & 康县 & 长江流域 & 嘉陵江水系 & 燕子河 & 1337 & 甘肃、陕西 \\
\hline 毛坝 & 成县 & 长江流域 & 嘉陵江水系 & 西汉水 & 10105 & 甘肃、陕西 \\
\hline 罐子沟 & 文县 & 长江流域 & 嘉陵江水系 & 白龙江 & 32190 & 甘肃、四川 \\
\hline
\end{tabular}

陇南市跨省河流全部属于长江流域嘉陵江水系, 途径甘肃, 最终流入陕西、四川。跨省断面主要有位于陇南市徽 县的大河店、虞关断面, 康县地区的托河断面, 成县地区的毛坝断面及临近四川省的罐子沟断面等。

\subsection{2. 陇南跨市断面}

表3 陇南市跨市流域。

\begin{tabular}{|c|c|c|c|c|c|c|c|}
\hline 所属县区 & 流域 & 水系 & 河流名称 & 河流级别 & 流域面积 & $\begin{array}{l}\text { 流经县级行政 } \\
\text { 区划 }\end{array}$ & $\begin{array}{l}\text { 上一级河流名 } \\
\text { 称 }\end{array}$ \\
\hline 武都区 & 长江流域 & 嘉陵江水系 & 西汉水 & 1 & 10105 & 天水、陇南 & 嘉陵江 \\
\hline 成县 & 长江流域 & 嘉陵江水系 & 西汉水 & 1 & 10105 & 天水、陇南 & 嘉陵江 \\
\hline 文县 & 长江流域 & 嘉陵江水系 & 白龙江 & 1 & 32190 & 甘南、陇南 & 嘉陵江 \\
\hline 宕昌 & 长江流域 & 嘉陵江水系 & 白龙江 & 1 & 32190 & 甘南、陇南 & 嘉陵江 \\
\hline 康县 & 长江流域 & 嘉陵江水系 & 西汉水 & 1 & 10105 & 天水、陇南 & 嘉陵江 \\
\hline 西和 & 长江流域 & 嘉陵江水系 & 西汉水 & 1 & 10105 & 天水、陇南 & 嘉陵江 \\
\hline 礼县 & 长江流域 & 嘉陵江水系 & 西汉水 & 1 & 10105 & 天水、陇南 & 嘉陵江 \\
\hline 徽县 & 长江流域 & 嘉陵江水系 & 白家河 & 1 & 2162 & 天水、陇南 & 嘉陵江 \\
\hline 徽县 & 长江流域 & 嘉陵江水系 & 马元河 & 2 & 265 & 天水、陇南 & 长丰河 \\
\hline 徽县 & 长江流域 & 嘉陵江水系 & 成家河 & 3 & 107 & 天水、陇南 & 马元河 \\
\hline 两当 & 长江流域 & 嘉陵江水系 & 红崖河 & 1 & 871 & 天水、陇南 & 嘉陵江 \\
\hline 两当 & 长江流域 & 嘉陵江水系 & 两当河 & 1 & 361 & 天水、陇南 & 嘉陵江 \\
\hline 两当 & 长江流域 & 嘉陵江水系 & 白家河 & 1 & 2162 & 天水、陇南 & 嘉陵江 \\
\hline
\end{tabular}

陇南市级河流交汇地区主要集中在天水市和甘南地区。其中，与天水市交接的河流有西汉水、白家河、马元河、 成家河、红崖河、两当河, 与甘南交接的河流主要有白龙江。

\section{2. 陇南市跨省断面污染物排放量}

\subsection{1. 实施依据}

依照《地表水环境质量标准》(GB3838-2002)中规定，地面水使用目的和保护目标，中国地面水分五大类，如下表 所示: 
表4 各类水体主要污染物排放标准。

\begin{tabular}{llllllll}
\hline 序号 & 分类 $(\mathbf{m g} / \mathbf{L})$ & & I 类 & II 类 & III类 & IV类 & V类 \\
\hline 1 & 化学需氧量 $(\mathrm{COD})$ & $\leq$ & 15 & 15 & 20 & 30 & 40 \\
2 & 氨氮(NH4+) & $\leq$ & 0.15 & 0.5 & 1 & 1.5 & 2 \\
3 & 总磷 & $\leq$ & 0.01 & 0.025 & 0.05 & 0.1 & 0.2 \\
4 & 总氮 & $\leq$ & 0.2 & 0.5 & 1 & 1.5 & 2 \\
\hline
\end{tabular}

\subsection{2. 跨省断面污染物排放总量}

依照以上排放标准及陇南市各断面多年平均河流径流量, 以各类水体的化学需氧量(COD)、氨氮两项指标的常年 平均浓度作为基本核算标准，在各类标准下，计算陇南市跨省断面水体污染物的排放总量，如下表所示。

表5 陇南市跨省断面污染物排放总量。

\begin{tabular}{|c|c|c|c|c|c|c|}
\hline 跨省断面 & 分类 & 河流径流量( $\left(\right.$ 亿 $\left.\mathrm{m}^{3}\right)$ & 化学需氧量(吨) & 氨氮(吨) & 总磷(吨) & 总氮(吨) \\
\hline \multirow{5}{*}{ 大河店 } & I 类水 & 2.80 & 4200.00 & 42.00 & 2.80 & 56.00 \\
\hline & II 类水 & 2.80 & 4200.00 & 140.00 & 7.00 & 140.00 \\
\hline & III类水 & 2.80 & 5600.00 & 280.00 & 14.00 & 280.00 \\
\hline & IV 类水 & 2.80 & 8400.00 & 420.00 & 28.00 & 420.00 \\
\hline & $\mathrm{V}$ 类水 & 2.80 & 11200.00 & 560.00 & 56.00 & 560.00 \\
\hline \multirow{5}{*}{ 虞关 } & I 类水 & 2.61 & 3915.00 & 39.15 & 2.61 & 52.20 \\
\hline & II 类水 & 2.61 & 3915.00 & 130.50 & 6.53 & 130.50 \\
\hline & III类水 & 2.61 & 5220.00 & 261.00 & 13.05 & 261.00 \\
\hline & IV 类水 & 2.61 & 7830.00 & 391.50 & 26.10 & 391.50 \\
\hline & $\mathrm{V}$ 类水 & 2.61 & 10440.00 & 522.00 & 52.20 & 522.00 \\
\hline \multirow{5}{*}{ 托河 } & I 类水 & 5.35 & 8025.00 & 80.25 & 5.35 & 107.00 \\
\hline & II 类水 & 5.35 & 8025.00 & 267.50 & 13.38 & 267.50 \\
\hline & III类水 & 5.35 & 10700.00 & 535.00 & 26.75 & 535.00 \\
\hline & IV 类水 & 5.35 & 16050.00 & 802.50 & 53.50 & 802.50 \\
\hline & $\mathrm{V}$ 类水 & 5.35 & 21400.00 & 1070.00 & 107.00 & 1070.00 \\
\hline \multirow{5}{*}{ 毛坝 } & I 类水 & 15.10 & 22650.00 & 226.50 & 15.10 & 302.00 \\
\hline & II 类水 & 15.10 & 22650.00 & 755.00 & 37.75 & 755.00 \\
\hline & III类水 & 15.10 & 30200.00 & 1510.00 & 75.50 & 1510.00 \\
\hline & IV 类水 & 15.10 & 45300.00 & 2265.00 & 151.00 & 2265.00 \\
\hline & $\mathrm{V}$ 类水 & 15.10 & 60400.00 & 3020.00 & 302.00 & 3020.00 \\
\hline \multirow{5}{*}{ 罐子沟 } & I 类水 & 85.50 & 128250.00 & 1282.50 & 85.50 & 1710.00 \\
\hline & II 类水 & 85.50 & 128250.00 & 4275.00 & 213.75 & 4275.00 \\
\hline & III类水 & 85.50 & 171000.00 & 8550.00 & 427.50 & 8550.00 \\
\hline & IV 类水 & 85.50 & 256500.00 & 12825.00 & 855.00 & 12825.00 \\
\hline & $\mathrm{V}$ 类水 & 85.50 & 342000.00 & 17100.00 & 1710.00 & 17100.00 \\
\hline
\end{tabular}

\section{3. 跨省断面污染物处理成本}

根据实地走访调查, 处理水体污染物时COD的单位成本为 3875 元/吨, 氨氮为4964元/吨。陇南市跨省断面各类水 体污染物处理成本如下表所示:

表6 陇南市各跨省断面水体污染治理成本。

\begin{tabular}{|c|c|c|c|c|c|}
\hline 断面 & 治理目标 & 化学需氧量减排量(吨) & 治理成本(万元) & 氨氮减排量(吨) & 治理成本(万元) \\
\hline \multirow{4}{*}{ 大河店 } & V 类-IV类 & 2800.00 & 1085.00 & 140.00 & 69.50 \\
\hline & IV类-III类 & 2800.00 & 1085.00 & 140.00 & 69.50 \\
\hline & III类-II 类 & 1400.00 & 542.50 & 140.00 & 69.50 \\
\hline & II 类- I 类 & 0.00 & 0.00 & 98.00 & 48.65 \\
\hline \multirow{4}{*}{ 虞关 } & V类-IV类 & 2610.00 & 1011.38 & 130.50 & 64.78 \\
\hline & IV类-III类 & 2610.00 & 1011.38 & 130.50 & 64.78 \\
\hline & III类- II 类 & 1305.00 & 505.69 & 130.50 & 64.78 \\
\hline & II 类- I 类 & 0.00 & 0.00 & 91.35 & 45.35 \\
\hline \multirow{4}{*}{ 托河 } & V 类-IV类 & 5350.00 & 2073.13 & 267.50 & 132.79 \\
\hline & IV类-III类 & 5350.00 & 2073.13 & 267.50 & 132.79 \\
\hline & III类-II 类 & 2675.00 & 1036.56 & 267.50 & 132.79 \\
\hline & II 类- I 类 & 0.00 & 0.00 & 187.25 & 92.95 \\
\hline \multirow{4}{*}{ 毛坝 } & $\mathrm{V}$ 类-IV类 & 15100.00 & 5851.25 & 755.00 & 374.78 \\
\hline & IV类-III类 & 15100.00 & 5851.25 & 755.00 & 374.78 \\
\hline & III类- II 类 & 7550.00 & 2925.63 & 755.00 & 374.78 \\
\hline & II 类- I 类 & 0.00 & 0.00 & 528.50 & 262.35 \\
\hline
\end{tabular}




\begin{tabular}{llllll}
\hline 断面 & 治理目标 & 化学需氧量减排量(吨) & 治理成本(万元) & 氨氮减排量(吨) & 治理成本(万元) \\
\hline & V 类-IV类 & 85500.00 & 33131.25 & 4275.00 & 2122.11 \\
\multirow{2}{*}{ 罐子沟 } & IV 类-III类 & 85500.00 & 33131.25 & 4275.00 & 2122.11 \\
& III类- II 类 & 42750.00 & 16565.63 & 4275.00 & 2122.11 \\
& II 类- I 类 & 0.00 & 0.00 & 2992.50 & 1485.48 \\
\hline
\end{tabular}

\section{4. 跨省断面水环境补偿方案}

\subsection{1. 近期补偿方案}

以《2016年甘肃省环境状况公报》公布的陇南市各跨 省断面的水质监测状况及考核目标为依据, 制定陇南市近 期跨省水环境补偿方案。从下表可以看出, 陇南市各跨省 断面水质监测现状良好, 均达到 I 类水质, 为保证下游水 环境生态健康及饮水安全做出了重要贡献。因此, 陕西省 及四川省应向陇南市提供补偿金额24534.91万元。其中, 陕西省需要向陇南市支付4361.69万元，包括大河店断面 的 660.64 万元、虞关 45.35 万元、托河 92.95 万元、毛坝 3562.75 万元; 四川省需要向陇南市支付 20173.21 万元, 主 要用于白龙江罐子沟断面。

表7 陇南市劣质水质赔偿方案。

\begin{tabular}{llll}
\hline 断面 & 水质现状 & 目标考核水质 & 补偿金额(万元) \\
\hline 大河店 & I 类 & III类 & 660.64 \\
虞关 & I 类 & II 类 & 45.35 \\
托河 & I 类 & II 类 & 92.95 \\
毛坝 & I 类 & III类 & 3562.75 \\
罐子沟 & I 类 & III类 & 20173.21 \\
陇南市 & - & - & 24534.91 \\
\hline
\end{tabular}

\subsection{2. 中期补偿方案}

为保证流域之间水环境保护工作走向规范、科学、系 统的可持续发展之路, 从长远发展角度来看, 各省之间不 仅需要制定水环境的生态补偿方案, 省内跨市流域的上游 之间也应积极开展水生态补偿工作。甘肃省多地河流与陇 南交汇，市级区域之间有关于水资源的使用及保护权益仍 存有争议, 为保证利益关联的各区域能进一步明晰自身的 权利与义务, 需要以签订补偿协议的方式, 通力合作, 切 实保障流域间局部与整体的水生态福利。
核算陇南市级水环境补偿成本时，由于缺少河流径流 量数据, 计算存在一定难度, 因此, 暂时缺少核算结果。 长远来看, 建立完善水生态补偿机制, 需要加强跨区域河 流的断面监测工作, 完善实时数据, 为保障水生态补偿工 作有序开展打下坚实基础。

\subsection{3. 远期目标}

开展陇南市水生态补偿工作, 不仅需要从跨省流域之 间的利益关系着手，核算目前水质状况的补偿成本，更需 考虑区域内部流域之间的矛盾与冲突，以签订补偿协议的 方式, 明晰水资源开发的权利与义务。流域上下游的各省、 各市之间要着眼大局, 通力合作, 以“约束”和“奖励”的方 式，共同维护水环境系统的健康、可持续发展。

为明确各省之间的“权、责、利”，按照“着眼大局， 互利共赢”的原则, 以《甘肃省水污染防治工作方案》公 布的水质目标为标准，将核算内容划分为：“优于标准”、 “劣于标准”两部分。其中，若陇南市向下游提供的水资源 质量高于甘肃省公布的该区域的考核目标即“优于标准”, 下游省份则应对上游省份因此放弃的发展权益进行经济 支付, 履行自身义务; 若陇南市为谋求自身发展向下游省 份提供的水资源质量低于甘肃省公布的考核目标即“劣于 标准”, 对下游地区的水生态环境及居民饮水质量造成了 不利影响, 则应主动对下游地区就此造成的损失进行经济 赔付。

\section{I.大河店断面}

大河店监测断面位于陇南市徽县洛河流域, 《甘肃省 水利公报》中公布的水质目标为III类水。当该断面水质优 于目标水质时, 下游的陕西省为相关受益者, 应根据相应 污染物处理成本，向陇南市提供补偿资金660.64、612.00 万元; 当该断面水质劣于目标水质时, 陕西省成为相关利 益的受损者, 陇南市应向其提供相应的赔偿 1150.72 、 2301.43万元，具体核算结果如下表所示:

表8 大河店断面补偿成本。

\begin{tabular}{|c|c|c|c|c|c|c|}
\hline 断面名称 & 河流径流量(亿 ( $\left.^{3}\right)$ & 水质状况 & 目标水质 & 减排COD(吨) & 减排氨氮(吨) & 水生态补偿(万元) \\
\hline \multirow{3}{*}{ 大河店 } & 2.80 & I 类水 & III类水 & 1400.00 & 238.00 & 660.64 \\
\hline & 2.80 & II 类水 & III类水 & 1400.00 & 140.00 & 612.00 \\
\hline & 2.80 & III类水 & III类水 & 0.00 & 0.00 & 0.00 \\
\hline 断面名称 & 河流径流量(亿m³) & 水质状况 & 目标水质 & 增排COD(吨) & 增排氨氮(吨) & 水生态赔付(万元) \\
\hline \multirow{2}{*}{ 大河店 } & 2.80 & IV 类水 & III类水 & 2800.00 & 140.00 & 1150.72 \\
\hline & 2.80 & $V$ 类水 & III类水 & 5600.00 & 280.00 & 2301.43 \\
\hline
\end{tabular}

\section{II.虞关断面}

虞关监测断面位于陇南市徽县洛河流域, 《甘肃省水 利公报》中公布的水质目标为 II 类水。当该断面水质优于 目标水质时，下游的陕西省为相关受益者，应根据相应污
染物处理成本，向陇南市提供补偿资金 45.17 万元; 当该 断面水质劣于目标水质时, 陕西省成为相关利益的受损者, 陇南市应向其提供相应的赔偿570.47、1367.62、3001.78 万元，具体核算结果如下表所示: 
表9 虞关断面补偿成本单位。

\begin{tabular}{|c|c|c|c|c|c|c|}
\hline 断面名称 & 河流径流量(亿吕) & 水质状况 & 目标水质 & 减排COD(吨) & 减排氨氮(吨) & 水生态补偿(万元) \\
\hline \multirow{2}{*}{ 虞关 } & 2.61 & I 类水 & II 类水 & 0.00 & 91.00 & 45.17 \\
\hline & 2.61 & II 类水 & II 类水 & 0.00 & 0.00 & 0.00 \\
\hline \multirow[t]{2}{*}{ 断面名称 } & 河流径流量(亿光) & 水质状况 & 目标水质 & 增排COD(吨) & 增排氨氮(吨) & 水生态赔付(万元) \\
\hline & 2.61 & III类水 & II 类水 & 1305.00 & 130.50 & 570.47 \\
\hline \multirow[t]{2}{*}{ 虞关 } & 2.61 & IV类水 & II 类水 & 3195.00 & 261.00 & 1367.62 \\
\hline & 2.61 & $\mathrm{~V}$ 类水 & II 类水 & 7245.00 & 391.50 & 3001.78 \\
\hline
\end{tabular}

III.托河断面

托河监测断面位于陇南市徽县洛河流域，《甘肃省水 利公报》中公布的水质目标为 II 类水。当该断面水质优于 目标水质时，下游的陕西省为相关受益者，应根据相应污
染物处理成本，向陇南市提供补偿资金 92.95 万元；当该 断面水质劣于目标水质时, 陕西省成为相关利益的受损者, 陇南市应向其提供相应的赔偿1169.35、3468.21、5674.12 万元，具体核算结果如下表所示:

表10 托河断面补偿成本。

\begin{tabular}{|c|c|c|c|c|c|c|}
\hline 断面名称 & 河流径流量(亿m³) & 水质状况 & 目标水质 & 减排COD(吨) & 减排氨氮(吨) & 水生态补偿(万元) \\
\hline \multirow[b]{2}{*}{ 托河 } & 5.35 & I 类水 & II 类水 & 0.00 & 187.25 & 92.95 \\
\hline & 5.35 & II 类水 & II 类水 & 0.00 & 0.00 & 0.00 \\
\hline \multirow[t]{2}{*}{ 断面名称 } & 河流径流量(亿m³) & 水质状况 & 目标水质 & 减排COD(吨) & 减排氨氮(吨) & 水生态补偿(万元) \\
\hline & 5.35 & III类水 & II 类水 & 2675.00 & 267.50 & 1169.35 \\
\hline \multirow[t]{2}{*}{ 托河 } & 5.35 & IV 类水 & II 类水 & 8025.00 & 722.25 & 3468.21 \\
\hline & 5.35 & $\mathrm{~V}$ 类水 & II 类水 & 13375.00 & 989.75 & 5674.12 \\
\hline
\end{tabular}

IV.毛坝断面

毛坝监测断面位于陇南市徽县洛河流域，《甘肃省水 利公报》中公布的水质目标为III类水。当该断面水质优于 目标水质时，下游的陕西省为相关受益者，应根据相应污
染物处理成本，向陇南市提供补偿资金3562.75、3300.41 万元; 当该断面水质劣于目标水质时，陕西省成为相关利 益的受损者，陇南市应向其提供相应的赔偿6226.03、 12452.06 万元，具体核算结果如下表所示:

表11 毛坝断面补偿成本。

\begin{tabular}{|c|c|c|c|c|c|c|}
\hline 断面名称 & 河流径流量(亿帛) & 水质状况 & 目标水质 & 减排COD(吨) & 减排氨氮(吨) & 水生态补偿(万元) \\
\hline & 15.10 & I 类水 & III类水 & 7550.00 & 1283.50 & 3562.75 \\
\hline 毛坝 & 15.10 & II 类水 & III类水 & 7550.00 & 755.00 & 3300.41 \\
\hline & 15.10 & III类水 & III类水 & 0.00 & 0.00 & 0.00 \\
\hline 断面名称 & 河流径流量(亿m³) & 水质状况 & 目标水质 & 减排COD(吨) & 减排氨氮(吨) & 水生态补偿(万元) \\
\hline 毛坝 & 15.10 & IV类水 & III类水 & 15100.00 & 755.00 & 6226.03 \\
\hline & 15.10 & $\mathrm{~V}$ 类水 & III类水 & 30200.00 & 1510.00 & 12452.06 \\
\hline
\end{tabular}

V.罐子沟断面

罐子沟监测断面位于陇南市徽县洛河流域，《甘肃省 水利公报》中公布的水质目标为III类水。当该断面水质优 于目标水质时，下游的陕西省为相关受益者，应根据相应
污染物处理成本，向陇南市提供补偿资金20173.21、 18687.74 万元; 当该断面水质劣于目标水质时，陕西省成 为相关利益的受损者, 陇南市应向其提供相应的赔偿 35253.36、53941.10万元，具体核算结果如下表所示:

表12 罐子沟断面补偿成本。

\begin{tabular}{|c|c|c|c|c|c|c|}
\hline 断面名称 & 河流径流量(亿草) & 水质状况 & 目标水质 & 减排COD(吨) & 减排氨氮(吨) & 水生态补偿(万元) \\
\hline \multirow{3}{*}{ 罐子沟 } & 85.50 & I 类水 & III类水 & 42750.00 & 7267.50 & 20173.21 \\
\hline & 85.50 & II 类水 & III类水 & 42750.00 & 4275.00 & 18687.74 \\
\hline & 85.50 & III类水 & III类水 & 0.00 & 0.00 & 0.00 \\
\hline 断面名称 & 河流径流量(亿m³) & 水质状况 & 目标水质 & 减排COD(吨) & 减排氨氮(吨) & 水生态补偿(万元) \\
\hline \multirow{2}{*}{ 罐子沟 } & 85.50 & IV类水 & III类水 & 85500.00 & 4275.00 & 35253.36 \\
\hline & 85.50 & $\mathrm{~V}$ 类水 & III类水 & 128250.00 & 8550.00 & 53941.10 \\
\hline
\end{tabular}

\subsection{4. 陇南市水生态补偿总体方案}

表13 陇南市水生态补偿整体方案。

\begin{tabular}{llll}
\hline 类型 & 近期目标 & 中期目标 & 远期目标(万元) \\
\hline 水质补偿 & 跨省断面 & 跨市断面 & 跨省断面+跨市断面 \\
所需资金 & 24534.91 & - & 24534.91 \\
\hline
\end{tabular}

陇南市外与下游地区的陕西省、四川省交接, 内与天 水市、甘南地区毗邻, 开展水生态补偿工作的近期目标要
立足当下，以其他省份的成功案例为依据，核算区域水质 现状与目标水质之间的补偿成本, 以2016年陇南市各跨省 
断面监测数据为准, 经过核算, 下游省份共需补偿陇南市 24534.91 万元; 开展水生态补偿的中期目标要充分考虑区 域内部子系统之间的利益冲突与矛盾, 积极制定市级单元 之间的水生态补偿方案, 推广跨省流域补偿工作的成功经 验, 设置断面监测站点, 完善水质监测数据, 精分补偿内 容; 长远来看, 陇南市补偿工作需要兼顾跨省流域及跨市 流域，明确区域之间的“权、责、利”关系，以“谁收益谁 补偿, 谁损害谁赔付”为原则, 协调地区发展, 保证水资 源的高效利用。

\section{5. 结论与讨论}

\section{1. 结论}

以甘肃省陇南市为典型研究区域, 核算陇南市各跨省 断面污染物排放总量, 根据污染物处理成本, 估算生态补 偿与生态赔付金额, 制定近、中、远生态补偿方案, 得出 以下几点结论:

(1)以陇南市公布的各跨省断面的水质监测状况及考 核目标为依据, 制定陇南市近期跨省水环境补偿方案。由 于陇南市各跨省断面水质监测现状良好, 为保证下游水环 境生态健康及饮水安全做出了重要贡献。因此, 陕西省及 四川省应向陇南市提供补偿金额24534.91万元。

(2)核算陇南市级水环境补偿成本时, 由于缺少河流径 流量数据, 计算存在一定难度, 暂时缺少核算结果。长远 来看, 建立完善水生态补偿机制, 需要加强跨区域河流的 断面监测工作, 完善实时数据, 为保障水生态补偿工作有 序开展打下坚实基础。

(3)陇南市远期补偿方案需要同时考虑跨省断面与跨 市断面的补偿工作, 因跨市断面暂时缺少数据, 整体补偿 方案的金额为 24534.91 万元。

\section{2. 讨论}

虽然陇南市跨省流域水生态补偿案例为打开省际间 补偿工作所遇到的困境提供了有益思路与借鉴, 但仍然无 法从根源上解决实施过程中所遇到的客观难题。生态补偿 制度作为一种有效的市场调节工具, 旨在利用经济手段对 环境负外部性进行正向激励。但是由于中国目前处于行政 集权、财政分权的现行制度之下，地方政府以经济利益为 主要追求目标, 忽视生态利益的现状就不会得到根本性的 改变, 各行政主体之间很难主动放弃自身的发展权益来维 护整体的生态福利。如果大江大河的源头区域及具有重要 生态地位的保护区能承担少量的经济发展责任, 则会大大 减少其自身与下游地区在经济发展与生态保护之间的冲 突, 从而更有利于扩大生态利益。能除此之外, 中国政府 在生态保护的纵向问责制度上没有形成系统、科学的考核 制度，政府官员的政绩考核仍然没有将环境指标列入主要 的考核范围, 这就大大降低了地方政府在保护环境方面的 积极能动性。

建立健全跨省流域水生态补偿制度, 对于中国走水资 源可持续道路有重要意义。在流域管理体制方面，应打破 传统以行政边界为核心划分的行政管理权, 尽量将管理权 限建立在资源要素的基础上。流域上下游之间要明确各自
的权利义务，规范协议内容，将补偿标准、补偿方式、补 偿资金上限等具体内容展开充分讨论。此外，应将生态指 标列入政府官员的政绩考核内容中，在限制开发区和禁止 开发区实施生态优先的考核制度, 生态功能重要的地区要 求承担相对少的经济发展任务, 突出生态优先的考核原则。 由于流域生态补偿工作涉及的利益相关方众多, 为保证补 偿工作的顺利开展, 应健全公众参与跨省流域水生态补偿 工作的法律机制, 广泛听取群众有关补偿标准、补偿方式 的意见，提高相关信息的透明程度。

\section{致谢}

西北师范大学学生 “创新能力提升计划”; 41801208 (青年基金); 41471453 (面上基金); 国家重点研 发计划课题 (2016YFC0503502)。

\section{参考文献}

[1] 乔旭宁,杨永菊,杨德刚.流域生态补偿研究现状及关键问题 剖析[J].地理科学进展, 2012, 31(4):395-402。

[2] Pagiola S, Ramírez E, Gobbi J, et al. Paying for the environmental services of silvopastoral practices in Nicaragua[J]. Ecological Economics, 2007, 64(2):374-385.

[3] Wunder S, Engel S, Pagiola S. Taking stock: A comparative analysis of payments for environmental services programs in developed and developing countries[J]. Ecological Economics, 2008, 65(65):834-852.

[4] Bennett D E, Gosnell H. Integrating multiple perspectives on payments for ecosystem services through a social-ecological systems framework[J]. Ecological Economics, 2015, 116:172-181.

[5] Wunder S, Albán M. Decentralized payments for environmental services: The cases of Pimampiro and PROFAFOR in Ecuador[J]. Ecological Economics, 2008, 65(4):685-698.

[6] 徐中民.甘肃省典型地区生态补偿机制研究[M].中国财政经 济出版社,2011。

[7] 王军锋,侯超波.中国流域生态补偿机制实施框架与补偿模 式研究——基于补偿资金来源的视角 [J].中国人口.资源与 环境, 2013, 23(2):23-29。

[8] 胡振华,刘景月,钟美瑞,等.基于演化博弯的跨界流域生态补 偿利益均衡分析一以漓江流域为例 [J].经济地理,2016, 36(6):42-49。

[9] 安晓明,郭志远.跨省域生态补偿的政府作为研究[J].广西社 会科学,2012(7):109-114。

[10] 郭少青.论我国跨省流域生态补偿机制建构的困境与突破 以新安江流域生态补偿机制为例 [J]. 西部法学评 论,2013(6):23-29。

[11] 李雪松,吴萍,曹婉吟.我国流域生态补偿标准的实践、问题 及对策 $[\mathrm{J}]$.水利经济, 2016, 34(6):34-37。 
[12] 赵越. 全国首个跨省流域水环境补偿试点[M].中国环境出版 社,2015。

[13] 张明波.跨省流域生态补偿机制研究[D].西北农林科技大 学,2013。

[14] 郭梅. 区域治理视角的跨省流域生态补偿机制研究一以 东江流域为例 [D].中国科学院大学, 2012。

[15] 田义文,张明波,刘亚男.跨省流域生态补偿: 从合作困境走向 责任共担[J].环境保护, 2012(15):37-40。

\section{作者简介}

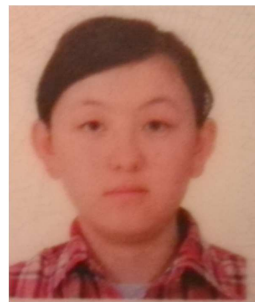

李洁(1990-), 女, 甘肃兰州人, 现为西 北师范大学在读博士研究生。主要研究 方向: 生态经济学。 